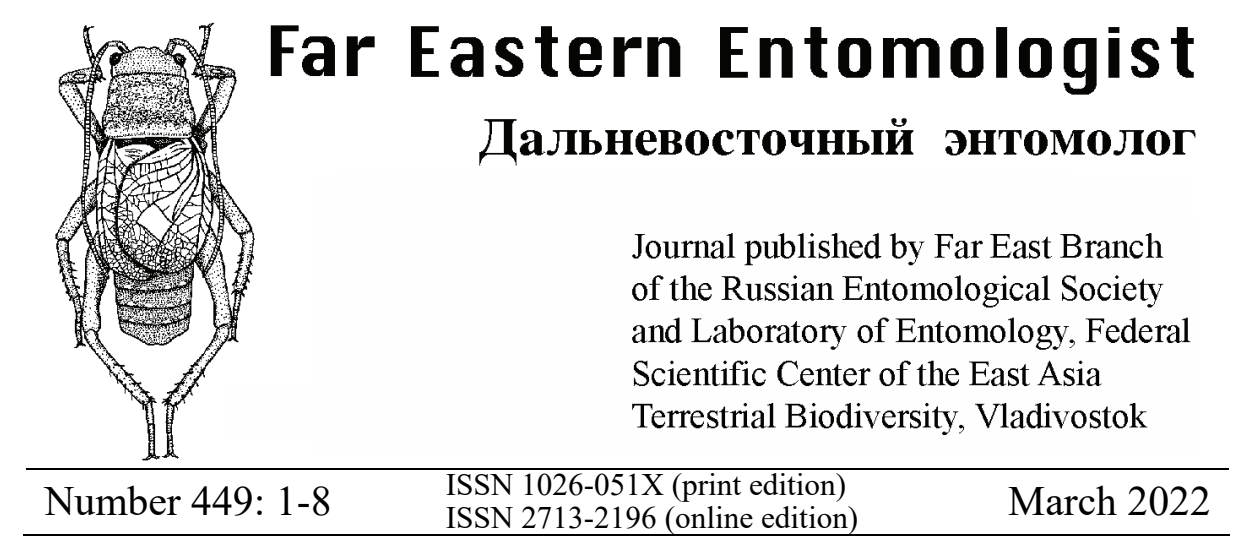

https://doi.org/10.25221/fee.449.1

http://zoobank.org/References/07EB7B53-C303-4DBA-AEB5-946430F51DCC

\title{
A NEW SPECIES OF THE BRISTLETAIL GENUS \\ CHARIMACHILIS WYGODZINSKY, 1939 (MICROCORYPHIA: MACHILIDAE) FROM EASTERN UKRAINE
}

V. G. Kaplin ${ }^{* *}$, V. V. Martynov ${ }^{2)}$

1) All-Ruissian Institute of Plant Protection. St. Petersburg, Pushkin, 196608, Russia. *Corresponding author,E-mail: ctenolepisma@mail.ru

2) Donetsk Botanical Garden, Donetsk, 83059, Ukraine.

Summary. Charimachilis petrophilus Kaplin, sp. n. is described from Donetsk region of Ukraine. New species is most similar to $C$. taurica Kaplin, 2021 and $C$. rostoviensis Kaplin, 2020 but differs from them by the ratio lengths of contact line and compound eyes, by number of hyaline spines on dorsal surface of 5-7th articles of maxillary palpus, by ratio of lengths of stylus and urocoxites VIII and IX, and by number of divisions in posterior gonapophysis. New species is also similar to $C$. ukrainensis Stach, 1958 and C. wahrmani Wygodzinsky, 1959 but distinguishes from them in the ratio of contact line to eye length, the distance between inner margins of ocelli to total width of compound eyes, the lengths of stylus and urocoxite IX, and from C. wahrmani also in the number of divisions in gonapophyses VIII and IX.

Key words: bristletails, Machilinae, taxonomy, new species, parthenogenesis, Palaearctic region.

В. Г. Каплин, В. В. Мартынов. Новый вид щетинохвосток рода Charimachilis Wygodzinsky, 1939 (Microcoryphia: Мachilidae) из Восточной Украины // Дальневосточный энтомолог. 2022. N 449. С. 1-8. 
Резюме. Из Донецкой области Украины описан Charimachilis petrophilus Kaplin, sp. n. Новый вид наиболее близок к C. taurica Kaplin, 2021 и C. rostoviensis Kaplin, 2020, но отличается от них относительной длиной линии контакта глаз, количеством бесцветных игловидных хет на дорсальной поверхности 5-7-го члеников нижнечелюстного щупика, соотношением длин грифельков и урококситов VIII и IX, а также числом члеников задних гонапофизов. Новый вид также сходен с C. ukrainensis Stach, 1958 и $C$. wahrmani Wygodzinsky, 1959, но отличается от обоих относительной длиной линии контакта глаз; соотношением длин грифельков и урококситов VIII и IX, а от C. wahrmani также числом члеников VIII и IX гонапофизов.

\title{
INTRODUCTION
}

Southwestern Palaearctic genus Charimachilis Wygodzinsky, 1939 (Microcoryphia: Machilidae, Machilinae) consists of 15 described species: C. palaestinensis Wygodzinsky, 1939 (Palestina), C. wahrmani Wygodzinsky, 1959 (Turkey), C. caucasica Kaplin, 2019 (Russia, Krasnodar region), C. abchasica Kaplin, 1999 (Abkhazia), C. manfredoniae Kaplin, 1999 (Italy), C. egatensis (Bach de Roca, 1983) (Italy), C. melitensis (Stach, 1958 (Malta), C. orientalis (Silvestri, 1908) (Greece), C. dentata Wygodzinsky, 1941 (Greece), C. relicta Janetschek, 1954 (Italy, Croatia, Austria, Greece),_C. armata Stach, 1958 (Bulgaria), C. ukrainensis Stach, 1958 (Ukraine), C. morozovi Kaplin, 2019 (Russia, Belgorod region), C. rostoviensis Kaplin, 2020 (Russia, Rostov region), and C. taurica Kaplin, 2021 (Crimea) (Kalin, 2019; Kaplin \& Martynov, 2020; Kaplin, 2021). Most species of this genus are parthenogenetic. Only females are known in 13 species. Males were found only in populations of C. caucasica Kaplin, 2019 and C. abchasica Kaplin, 2017 from the Great Caucasus. This makes it difficult to identify them.

\section{MATERIAL AND METHODS}

The bristletails were collected in Donetsk region and stored in 75\% ethanol. The holotype (female) and two paratypes (females) were dissected and mounted in Berlese fluid on glass microscope slides. The figures were made using a microscope and a drawing tool. The types of the new species are deposited in the collection of the Al-Russian Institution of Plant Protection (VIZR), Pushkin, St. Petersburg, Russia.

\section{DESCRIPTION OF NEW SPECIES}

\author{
Family Machilidae Grassi, 1888
}

Subfamily Machilinae Grassi, 1888

Genus Charimachilis Wygodzinsky, 1939

Type species: Praemachilis orientalis Silvestri, 1908. 


\section{Charimachilis petrophilus Kaplin, sp. n.}

http://zoobank.org/NomenclaturalActs/102AEA04-F2FC-441A-A0CA-23557FE47991

Figs 1-14

TYPE MATERIAL. Holotype - 9 , Ukraine: Donetsk region, near Dmitrievka, $47^{\circ} 56^{\prime} 03^{\prime \prime} \mathrm{N}, 38^{\circ} 56^{\prime} 15^{\prime \prime} \mathrm{E}, 50 \mathrm{~m}$, petrophytic steppe, under stones, 23.III 2020, leg. V. Martynov (VIZR) (in slides). Paratypes: $5 \%$, same locality, data and collector as for holotype (VIZR) ( 2 in slides; $3 \circ$ in $75 \%$ ethanol).

DESCRIPTION. Female. Body length 7.6-9.2 mm; body width 2.2-2.3 mm; antennal length $5.0-5.6 \mathrm{~mm}$; cercal length $2.9-3.3 \mathrm{~mm}$; total eyes width $0.89-0.94$ $\mathrm{mm}$, eye length $0.43-0.46 \mathrm{~mm}$; paired ocelli width $0.39-0.41 \mathrm{~mm}$, length $0.14-0.16$ $\mathrm{mm}$. Coxal styli length $0.51-0.54 \mathrm{~mm}$. Ovipositor length $1.4-1.5 \mathrm{~mm}$.

General body color whitish, with purple-brown hypodermal pigment of faint or medium intensity only on antennal base, frons, gena, labrum, mandible, stipes and galea of maxilla, first article of maxillary palpus, coxa. Color of scales on upper and lower surface of the body brown. Antennae shorter than body. Distal chains of flagellum divided into 6-12 annuli (Fig. 1). Cercus 0.32-0.39 times as long as body length. Apex of cercus with one large and one lateral easily broken spike (Fig. 2). Divisions of cerci, except for apical three, with 1-3 colorless supporting macrochaetae on inner side.

Compound eyes black. Ratio of length to width of compound eye about 0.90 0.94; ratio of contact line length to eye length $0.42-0.47$. Paired ocelli shoe-shaped, dark brown with white rim, located in front of eyes. Distance between inner margins of ocelli about $0.14-0.15$ and between their outer margins $0.80-0.86$ total width of compound eyes (Fig. 3).

Apical article of maxillary palpus $0.96-1.04$ times as long as preceding one. Dorsal surface of $7 \mathrm{th}$, 6th, and 5th articles of maxillary palpus with 13,11, and 5 hyaline spines, respectively (Fig. 4). Apical article of labial palpus triangularly oval, 2.5-2.7 times as long as wide (Fig. 5). Mandibles with four distal teeth (Fig. 6).

Fore and middle femur and tibia widened. Ratios of lengths to widths of femur, tibia and tarsus as shown in Table 1. Ratio of length of 3rd tarsomere to total length of tarsus $0.32-0.34$. Pretarsus with well developed claws and with two support protrusions (Fig. 7). Ventral surface of femora, tibiae and tarsi with spine-like chaetae as shown in Table 2. Middle and hind legs with coxal styli (Fig. 8). Ratio of styli length to width of middle and hind coxae about 1.6-1.8.

Abdominal segments I-VII with $1+1$ eversible vesicles. Posterior angle of urosternites sharp, about $60-80^{\circ}$. Ratios of lengths of urosternite and urocoxite IIVI 0.65-0.70; urostylus (without apical spine) and urocoxite II-VII 0.46-0.55, VIII -0.86 , IX -0.50 ; apical spine and urostylus (without apical spine) II-VIII 0.44 0.46 , IX - 0.31 (Figs 9-13). Inner posterior lobes of urocoxites VII protruding; ratio of length to width of one lobe about 0.66 (Fig. 10).

Urocoxites IX with $1-2+1-2$ outer and 5-7 +5-7 inner sublateral, VIII with 2 $3+2-3$, VII with 1-2 + 1-2 sublateral spines (Figs 9, 11, 12). Urocoxites I-VI without sublateral spines. 


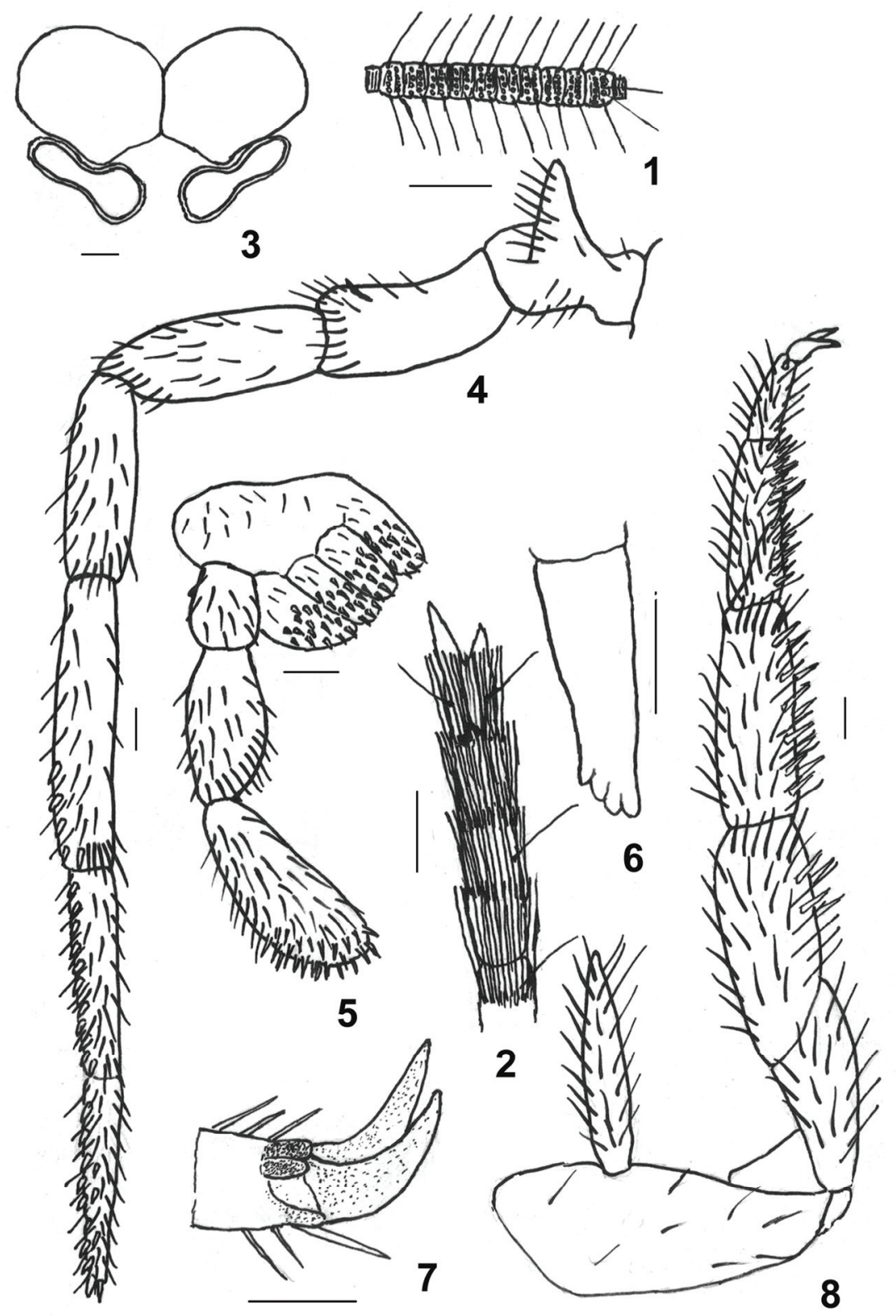

Figs 1-8. Charimachilis petrophilus Kaplin, sp. n., holotype $q(2,4-8)$ and paratype + $(1,3) .1$ - chain of distal part of flagellum; 2 - apex of cercus; 3 - compound eyes and paired ocelli (front view); 4 - maxillary palpus; 5 - labium (part) and labial palpus; 6 - distal part of mandible; 7 - pretarsus; 8 - hind leg. Scale bars $=0.1 \mathrm{~mm}$. 


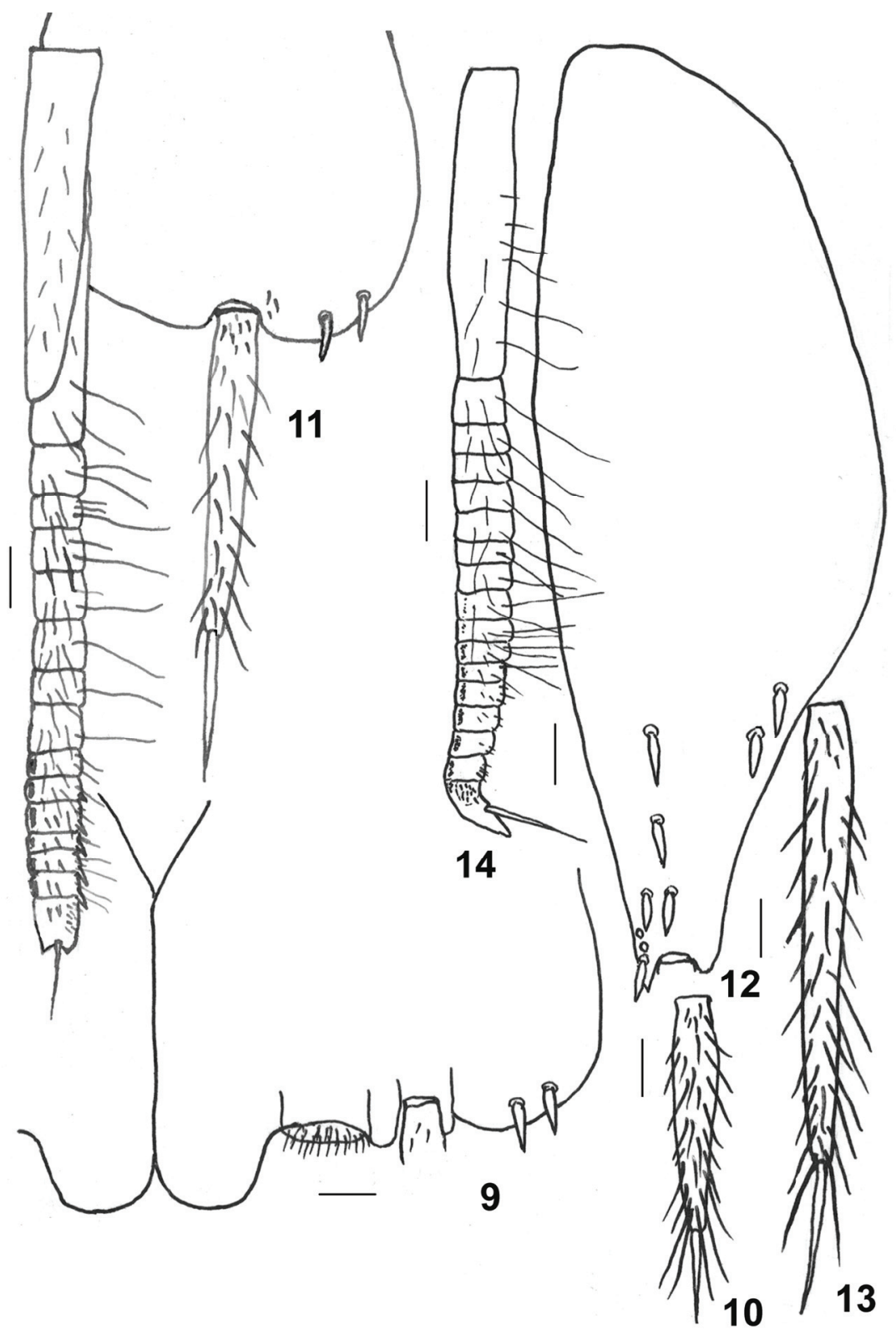

Figs 9-14. Charimachilis petrophilus Kaplin, sp. n., holotype +.9 - urosternite and urocoxites VII (part); 10 - stylus of urocoxite VII; 11 - coxite VIII with anterior gonapophysis; 12 - coxite IX; 13 - stylus of urocoxite IX; 14 - posterior gonapophysis. Scale bars $=0.1 \mathrm{~mm}$. 
Ovipositor weakly sclerotized, thickened, completely concealed by urocoxites IX, typical of genus Charimachilis. Anterior and posterior gonapophyses with respectively 16 and 17 divisions (Figs 11,14 ). Ultimate division of anterior gonapophysis with preapical spine and 2 small apical lateral projections, one of which is pointed and sclerotized. Apical spines as long as 2 apical divisions combined. Anterior gonapophysis with 4 or 5 lateral digging spikes. Posterior gonapophyses with well developed, sclerotized curved apical horn and preapical spine, as long as 3 or 4 apical divisions combined. Distribution of sensory and simple chaetae on divisions of anterior and posterior gonapophyses as in Figs 11 and 14.

Male. Unknown.

Table 1. Ratios of lengths to widths of main leg articles in Charimachilis petrophilus sp. n.

\begin{tabular}{l|c|c|c}
\hline \multirow{2}{*}{\multicolumn{1}{c|}{ Segments }} & \multicolumn{3}{|c}{ Pair of legs } \\
\cline { 2 - 4 } & fore & middle & hind \\
\hline Tarsus & 4.72 & 4.17 & 4.53 \\
\hline Tibia & 2.09 & 2.02 & 3.00 \\
\hline Femur & 2.07 & 2.38 & 3.08 \\
\hline Coxa & 2.16 & 2.66 & 2.78 \\
\hline
\end{tabular}

Table 2. Number of spines on the legs of female Charimachilis petrophilus sp. $\mathrm{n}$.

\begin{tabular}{l|l|c|c|c}
\hline \multicolumn{2}{c}{ Segments } & \multicolumn{3}{c}{ Pair of legs } \\
\cline { 3 - 5 } \multirow{3}{*}{ Tarsomeres } & 1st & fore & middle & hind \\
\cline { 2 - 5 } & 2nd & 4 & 6 & $8-10$ \\
\cline { 2 - 5 } & 3rd & 8 & $7-8$ & $9-11$ \\
\hline Tibia & 0 & 0 & 0 \\
\hline Femur & $0-3$ & $5-6$ & $10-12$ \\
\hline
\end{tabular}

DIFFERENTIAL DIAGNOSIS. Charimachilis petrophilus sp. n. most closely resembles $C$. taurica and $C$. rostoviensis in ratio of lengths of apical article of maxillary palpus and the preceding one; posterior angle of urosternites II-V; ratio of lengths of stylus (without apical spine) and urocoxite II-VII; number of inner sublateral spines on urocoxite IX; divisions and lateral digging spikes on anterior gonapophyses (Table 3). New species differs from $C$. taurica and $C$. rostoviensis by the ratio of contact line length to eye length; number of hyaline spines on dorsal surface of 5th, 6th and 7th articles of maxillary palpus; ratio of lengths of stylus (without apical spine) and urocoxites VIII and IX; number of divisions in posterior gonapophysis. C. petrophilus sp. n. differs from C. ukrainensis and C. wahrmani by 
Table 3. Differences between Chariumachilis petrophilus sp. n., C. rostoviensis, $C$. taurica, C. ukrainensis, and C. wahrmani.

\begin{tabular}{|c|c|c|c|c|c|c|}
\hline \multirow{2}{*}{\multicolumn{2}{|c|}{$\begin{array}{l}\text { Morphological } \\
\text { characters }\end{array}$}} & \multicolumn{5}{|c|}{ Species } \\
\hline & & petrophilus & rostoviensis & taurica & ukrainensis & wahrmani \\
\hline \multicolumn{2}{|c|}{$\begin{array}{l}\text { Ratio lengths of cercus } \\
\text { and body }\end{array}$} & $0.32-0.39$ & $0.42-0.47$ & $?$ & 0.27 & $?$ \\
\hline \multicolumn{2}{|c|}{$\begin{array}{l}\text { Ratio of compound eye } \\
\text { length to width }\end{array}$} & $0.90-0.94$ & 0.86 & 1.0 & 0.82 & 0.9 \\
\hline \multicolumn{2}{|c|}{$\begin{array}{l}\text { Ratio of contact line } \\
\text { length to eye length }\end{array}$} & $0.42-0.47$ & $0.33-0.35$ & 0.52 & 0.40 & 0.45 \\
\hline \multicolumn{2}{|c|}{$\begin{array}{l}\text { Ratio of distance } \\
\text { between inner margins } \\
\text { of ocelli to total width of } \\
\text { compound eyes }\end{array}$} & $0.14-0.15$ & $0.08-0.10$ & 0.15 & $0.10-0.11$ & 0.17 \\
\hline \multirow{3}{*}{\multicolumn{2}{|c|}{\begin{tabular}{l|} 
Number of hyaline \\
spines on dorsal \\
surface of articles \\
of maxillary palpus
\end{tabular}}} & 13 & 17 & $15-16$ & $?$ & $?$ \\
\hline & & 11 & $13-14$ & 16 & $?$ & $?$ \\
\hline & & 5 & $8-9$ & $3-4$ & $?$ & $?$ \\
\hline \multicolumn{2}{|c|}{$\begin{array}{l}\text { Ratio of length to width } \\
\text { of apical article of labial } \\
\text { palpus }\end{array}$} & $2.5-2.7$ & $2.3-2.4$ & $2.6-2.7$ & $?$ & $?$ \\
\hline \multirow{3}{*}{$\begin{array}{l}\text { Ratio of lengths } \\
\text { of stylus } \\
\text { (without apical } \\
\text { spines) } \\
\text { to urocoxite }\end{array}$} & $\begin{array}{l}\text { II- } \\
\text { VII }\end{array}$ & $0.46-0.66$ & $0.48-0.53$ & $0.47-0.50$ & $0.62-0.68$ & 0.40 \\
\hline & VIII & 0.86 & 0.95 & 0.74 & 0.9 & 0.55 \\
\hline & IX & 0.50 & 0.46 & 0.55 & 0.75 & 0.45 \\
\hline \multicolumn{2}{|c|}{$\begin{array}{l}\text { Number of sublateral } \\
\text { spines in urocoxite VIII }\end{array}$} & $2-3$ & $2-3$ & 3 & $1-2$ & $?$ \\
\hline \multirow{2}{*}{$\begin{array}{l}\text { Number of } \\
\text { sublateral } \\
\text { spines in } \\
\text { urocoxite IX }\end{array}$} & outer & $1-2$ & 1 & 3 & 1 & 0 \\
\hline & inner & $5-7$ & 6 & $6-7$ & $6-7$ & 3 \\
\hline \multirow{2}{*}{$\begin{array}{l}\text { Number of } \\
\text { gonapophyses } \\
\text { divisions }\end{array}$} & VIII & 16 & 17 & 17 & 15 & 15 \\
\hline & IX & 17 & 15 & 16 & 17 & $12-13$ \\
\hline \multicolumn{2}{|c|}{$\begin{array}{l}\text { Number of lateral } \\
\text { digging spikes on } \\
\text { anterior gonapophyses }\end{array}$} & $4-5$ & $4-5$ & $4-5$ & $3-4$ & $5-6$ \\
\hline
\end{tabular}

the ratios of contact line to eye length, distance between inner margins of ocelli to total width of compound eyes, lengths of stylus (without apical spine) and urocoxite IX; and from C. wahrmani in the number of divisions in gonapophyses VIII and IX (Table 3 ). The new species is probably parthenogenetic, similar to most its congeners.

ETYMOLOGY. The new species is named after the predominant habitat type. 


\section{REFERENCES}

Kaplin, V.G. 2019. A review of the distribution and phylogenetic relationships of bristletails of the genus Charimachilis Wygodz. (Archaeognatha, Machilidae) with descriptions of larvae of Ch. caucasica Kapl. and of a new species from Belgorod Province. Entmological Review, 99(1): 91-115. DOI: 10.1134/S0013873819010135

Kaplin, V.G. 2021. A new species of bristletails of the genus Charimachilis (Microcoryphia: Machilidae) from Crimea. Russian Entomological Journal, 30(2): 123-128.

Kaplin, V.G. \& Martynov, V.V. 2020. Three new species of bristletails of the families Meinertellidae and Machilidae (Archaeognatha) from Ukraine and Southern Russia. Acta Entomologica Musei Nationalis Pragae, 60(2): 463-474. DOI: 10.37520/aemnp.2020.30. 